\title{
Lack of Cytotoxicity of the Colorant in Conjugated Linoleic Acid against Human Cancer and Normal Cells
}

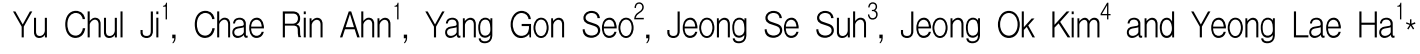 \\ ${ }^{1}$ Division of Applied Life Sciences (BK21 Program), Graduate School, and Institute of Agriculture \& Life Science, Gyeongsang National \\ University, Jinju 660-701, Korea \\ ${ }^{2}$ Department of Chemical \& Bioengineering, and ${ }^{3}$ Department of Mechanical Engineering, Engineering Research Institute, College of Engineering \\ Gyeongsang National University, Jinju 660-701, Korea \\ ${ }^{4} H K$ Biotech Co, Ltd, Jinju 660-844, Korea
}

Received July 1, 2012 /Revised August 7, 2012 /Accepted August 9, 2012

\begin{abstract}
The cytotoxicity of the colorant in conjugated linoleic acid (CLA) was investigated in human cancer cell lines and a normal human cell line. Commercially-available CLA with a brown color (designate crude CLA; c-CLA) was distilled in a vacuum $\left(10 \mathrm{mmHg}-220^{\circ} \mathrm{C}, 10 \mathrm{mmHg}-235^{\circ} \mathrm{C}, 10 \mathrm{mmHg}-240^{\circ} \mathrm{C}\right.$, and $20 \mathrm{mmHg}-260^{\circ} \mathrm{C}$ ) for $30 \mathrm{~min}$ to obtain pure CLA (distilled CLA; d-CLA) and dark brown-colored CLA (residual CLA; r-CLA) samples. No color intensity was shown in the d-CLA sample obtained under $10 \mathrm{mmHg}-220^{\circ} \mathrm{C}$ conditions of distillation when the $\mathrm{L}$ (brightness), a (red/blue), and b (yellow/green) parameters were analyzed, whereas the r-CLA sample showed a dark brown color. The composition of CLA isomers in both the d- and r-CLA samples, as compared to that of the c-CLA sample, was not significantly different when analyzed by gas chromatography. When the cytotoxicity of the r-CLA and d-CLA samples obtained under $10 \mathrm{mmHg}-220^{\circ} \mathrm{C}$ conditions were compared against human breast cancer cells (MCF-7), human lung cancer cells (A-549), human colon cancer cells (HT-29), human prostate cancer cells (PC-3), and human neuroblastoma cells (SK-N-SH), no significant cytotoxicity was seen in the cell lines. These results suggest that the color or colorant in the CLA samples did not have any effects on the proliferation of human cancer and normal cells and imply that the colorant in commercially available CLA samples is safe for human consumption.
\end{abstract}

Key words : Conjugated linoleic acid, cytotoxicity, human cancer cells, human neuroblastoma cells, distillation

\section{서 론}

Conjugated linoleic acid (CLA)는 1987년에 최초로 ground beef에서 7,12-di-methylbenz[a]anthrathene (DMBA)으로 유 발한 mouse skin carcinogenesis를 억제하는 항암물질로 분리 및 동정되었다[6]. 그 이후 CLA는 여러 인체암세포와 발암물 질로 유발한 동물실험에서 그 항암성이 인정되었고 그 기작도 연구되었다 $[2,3,6,8,9,11,14,21,23,24]$. 또한 CLA는 항암효과 외 에 면역증진효과, 혈중 cholesterol 감소효과, 체지방감소효과 등 인체에 도움이 되는 기능성 물질임이 많은 연구자들에 의 해 밝혀졌다 $[1,4,7,20]$. 따라서 $21 \mathrm{C}$ 에 개발된 최고의 기능성 물 질로서 인정을 받고 있는 CLA는 1997년에 인체 체지방을 감 소에 도움을 줄 수 있는 diet supplement로 미국에서부터 시판 되기 시작하여 현재 유럽을 비롯한 많은 국가에서 시판되고 있다.

$\mathrm{CLA}$ 는 다양한 이성체 $\left(\mathrm{C}_{7}-\mathrm{C}_{12}\right.$ 의 cis, trans 이성체)를 갖는

\footnotetext{
*Corresponding author

Tel : +82-55-772-1964, Fax : +82-55-772-1969

E-mail : ylha@gnu.ac.kr
}

다. 그 중 c9,t11-CLA 이성체는 B. fibrisolvens와 같은 반추위에 서식하는 미생물에 의해 linoleic acid로부터 합성되어 반추위 동물의 조직이나 우유에 축적되고 있다 $[15,18]$. 또한 인체의 장에 서식하는 L. reuteri와 같은 bacteria에 의해서도 합성되기 도 하고 버섯인 Agaricus blazei에 의해서도 합성된다.[5,10,12]. 그러나 linoleic acid로부터 alkaline isomerization에 의해 합 성되는 CLA에는 많은 CLA 이성체( $\mathrm{C}_{7}-\mathrm{C}_{12}$ 의 cis, trans 이성체) 가 함유되어 있다[16,22]. 이 중 c9,t11-CLA와 $\mathrm{t} 10, \mathrm{c} 12-\mathrm{CLA}$ 이 성체가 major로 각각 약 $40 \%$ 이상 차지하고 있다. 이들 두 이성체의 항암성 효과는 암세포의 종류 및 실험에 사용한 발 암물질에 따라 상이하지만, 체지방 감소 및 분해효과는 $\mathrm{t} 10, \mathrm{c} 12-\mathrm{CLA}$ 이성체가 c9,t11-CLA 이성체보다 우수함이 동물 및 인체연구에서 밝혀졌다[21].

CLA는 무색이다. 소량의 무색 순수 CLA가 요구되는 in vitro 연구에서는 미생물에 의해 free linoleic acid를 c9,t11-CLA 로 생합성하거나 linoleic acid를 alkaline isomerization으로 합성한 CLA (c9,t11-CLA와 t10,c12-CLA가 major 이성체)로부 터 분리하여 사용하였다[16]. 그러나 대량의 CLA를 요구하는 in vivo 연구에서는 linoleic acid가 다량 함유된 유지(safflower 
seed oil, sunflower seed oil 등)를 alkaline isomerization하여 사용하였다. 이 합성 CLA에는 식물성유로부터 유래하는 다양 한 색소에 의해 황색-황갈색의 색깔을 띠고 있다. 현재까지 수 천편의 CLA에 관한 연구논문 중 소량의 CLA시료가 필요 로 하는 cell-line 연구 이외의 거의 모든 in vivo 및 in vitro 연구에는 alkaline isomerization된 황색의 CLA 시료가 이용 되었다. 그러나 이 CLA 시료에 함유된 색소의 영향에 관한 연구는 문헌에 찾아 볼 수가 없다.

본 연구에서는 식물성유를 alkaline isomerization로 합성한 CLA의 색깔에 대한 세포독성을 연구하였다. 다이어트용으로 시판되는 CLA제품(safflower seed oil로부터 합성)을 구입하 여 CLA 색깔의 인체암세포와 정상세포에 대한 독성을 조사하 였다. CLA 색소의 분리가 쉽지 않아 황색 CLA 시료(crude CLA; c-CLA)를 감압증류 하여 CLA를 제거(distilled CLA; $\mathrm{d}$-CLA)하고 남은 황갈색 CLA (residual CLA; r-CLA)에 대한 세포독성을 d-CLA와 비교하였다.

\section{재료 및 방법}

\section{재료}

황색 CLA 시료(c-CLA)는 시판 다이어트용 CLA (safflower seed oil로부터 alkaline isomerization 하여 합성)를 구입하였 다. 인체암세포인 유선암세포(MCF-7), 폐암세포(A-549), 직장 암세포(HT-29), 전립선암세포(PC-3)와 정상세포인 인체신경 모세포(SK-N-SH)는 한국세포주은행(Korea Cell Line Bank, Seoul, Korea)에서 구입하였다. Roswell Park Memorial Institute (RPMI) 1640, Dulbecco's Modified Eagle Medium/Ham'F-12 nutrient mixture (DMEM/F-12), fetal bovine serum (FBS), penicillin $(10,000 \mathrm{U} / \mathrm{ml}) /$ streptomycin $(10,000 \mu \mathrm{g} / \mathrm{ml})$, phosphate buffer saline (PBS), 0.25\% trypsin-EDTA, fatty acid-free bovine serum albumin (BSA), 3-(4,5-dimethylthiazol-2-yl)-2, 5-diphenyltetrazolium bromide (MTT)는 Amresco (Solon, $\mathrm{OH}$ )에서 구입하였고, dimethyl sulfoxide (DMSO), heptadecanoic acid (C17:0)는 SigmaAldrich (St. Louis, MO)에서 구입하였다. Cell culture dish 또는 plate는 Nunc (NY, USA)에서 구입하였다. CLA 증류는 경상대학교 공과대학 분리공정연구실의 감압회분증류 장치 를 사용하였다. 그 외 시약은 1 급 또는 특급을 사용하였다.

\section{$\mathrm{CLA}$ 의 감압회분증류}

CLA의 증류는 내압을 $10 \sim 20 \mathrm{mmHg}$ 로 설정하고 내부온도 를 $220 \sim 260^{\circ} \mathrm{C}$ 조정하여 각 조건에서 30 분 증류하였다. c-CLA 시료로부터 d-CLA를 제거하고 r-CLA시료를 얻었다.

\section{CLA 조성분석}

CLA 시료에 함유된 이성체는 park 등[22]의 방법에 준하여
분석하였다. CLA $(50 \mathrm{mg})$ 를 internal standard인 heptadecanoic acid (5 mg), $1.0 \mathrm{~N}$ sulfuric acid/methanol 용액 $3 \mathrm{ml}$ 와 혼합한 후 $55^{\circ} \mathrm{C}$ 에서 5 분 반응하여 methylation 시켰다. CLA methyl ester는 FID와 fused silica capillary column Supelcowax-10 (60 m × $0.32 \mathrm{~mm}$, i.d., $25 \mu \mathrm{m}$ film thickness) 이 장착된 GC (Hewlett-Packard 5890)로 분석하였다. Oven temperature는 $2^{\circ} \mathrm{C} / \mathrm{min}$ 로 $180^{\circ} \mathrm{C}-200^{\circ} \mathrm{C}$ 등온 시키고 30 분간 유지시켰다. Injection port 와 detector temperatures는 각각 $240^{\circ} \mathrm{C}$ 와 $260^{\circ} \mathrm{C}$ 이었다. Nitrogen $(99.9 \%)$ 의 flow rate를 2 $\mathrm{ml} / \mathrm{min}$ 로 하여 carrier gas로 사용하였다. CLA 이성체는 CLA standard 이성체의 relative retention time과 비교하여 분석하였다[22].

\section{색도분석}

CLA 시료의 색도는 Minolta model CM-3600d colorimeter (Tokyo. Japan)를 이용하여 측정하였다. 색도는 $\mathrm{L}$ (brightness), a (red/green), and b (yellow/blue) 값으로 표시 하였다.

\section{$\mathrm{CLA}$ 시료 처리 및 세포독성 assay}

CLA 시료는 fatty acid-free BSA와 complex를 만들어 세포 배양에 사용하였다[11]. MCF-7 세포와 SK-N-SH 세포는 $10 \%$ FBS와 penicillin/streptomycin이 함유된 DMEM/F-12 배지 에서 그리고 PC-3과 A-549 및 HT-29는 $10 \%$ FBS와 penicillin/streptomycin이 함유된 RPMI 1640 배지에서 $5 \% \mathrm{CO}_{2}$ 가 공급되는 $37^{\circ} \mathrm{C}$ 배양기에서 배양하였다[11,17]. 세포가 $80 \%$ 정도 자라면 배지를 제거한 후 PBS로 3회 세척하고 $0.25 \%$ trypsin-EDTA 용액 $1 \mathrm{ml}$ 를 5분간 처리하고 원심분리(1,500 $\mathrm{rpm}$ )하여 세포를 분리하였다. 이들 세포를 24-well plate $\left(1.5 \times 10^{5}\right.$ cells $/ 0.5 \mathrm{ml} /$ well $)$ 에서 24 시간 배양하였다. 이들로부 터 배지를 제거하고 PBS로 3회 세척 후 serum free media (SFM)를 넣고 CLA 시료(c-CLA, d-CLA, r-CLA)를 농도별(0, $10,40 \mu \mathrm{M})$ 로 처리하고 48 시간 배양하였다.

처리된 CLA 시료의 독성은 MTT assay로 측정하였다 [23,24]. CLA 시료가 처리된 세포의 배지를 제거하고, PBS로 세척(3회)하고, MTT 시약( $5 \mathrm{mg} / \mathrm{ml}$ PBS)을 well당 $100 \mu \mathrm{l}$ 가하 고 $37^{\circ} \mathrm{C}$ 에서 3 시간 배양하였다. 그 후 MTT solution을 제거하 고 PBS로 세척한 뒤 DMSO를 well당 $200 \mu$ 씩 처리한 뒤 formazan crystal을 녹였다. 이를 새로운 96-well plate의 well당 $100 \mu \mathrm{l}$ 옮겨 Anthos 2020 model microplate reader (Anthos Labtech Instruments, Wals, Austria)로 $570 \mathrm{~nm}$ 에서 흡광도를 측정하여 세포의 생육정도를 계산하였다.

\section{통계분석}

Data는 mean \pm standard deviation (SD)으로 나타내었고, Statistical Analysis System (SAS) 프로그램을 이용하여 
one-way ANOVA와 Duncan's multiple range test를 통해 분 석하였다. Data의 유의수준은 $p<0.05$ 이상으로 하였다.

\section{결과 및 고찰}

\section{C-CLA로부터 r-CLA의 분리}

시판 CLA의 색깔에 대한 세포독성을 연구할 목적으로 c-CLA 시료를 감압증류 장치(Fig. 1)에 넣고 압력을 $10 \mathrm{mmHg}$ 로 고정하고 온도를 $220^{\circ} \mathrm{C}, 235^{\circ} \mathrm{C}, 240^{\circ} \mathrm{C}$ 로 올리면서 30 분 증 류하였고, 또한 압력을 $20 \mathrm{mmHg}$ 로 조정하고 온도를 $260^{\circ} \mathrm{C}$ 로 높여서 30 분간 증류하여 d-CLA 시료와 색소를 함유하는 $\mathrm{r}$-CLA 시료로 분리하였다(Fig. 2). 증류조건 $10 \mathrm{mmHg}-220^{\circ} \mathrm{C}$ 에서 얻은 d-CLA 시료의 색깔이 육안으로 판정하기에는 무색 에 가까웠고, 온도를 $235^{\circ} \mathrm{C}$ 및 $240^{\circ} \mathrm{C}$ 로 올려 증류한 $\mathrm{d}-\mathrm{CLA}$ 시료의 색깔은 $10 \mathrm{mmHg}-220^{\circ} \mathrm{C}$ 에서 증류한 것보다 연한 갈색 을 띄었다. 마찬가지로 압력을 $20 \mathrm{mmHg}$ 로 조정하고 온도를 $260^{\circ} \mathrm{C}$ 높여서 중류 한 d-CLA 시료의 색깔도 다른 조건 $(10$ $\mathrm{mmHg}-235^{\circ} \mathrm{C}$ 와 $10 \mathrm{mmHg}-240^{\circ} \mathrm{C}$ )에서 증류한 d-CLA 시료와
마찬가지로 연한 갈색을 띄었다. 그러나 모든 r-CLA 시료의 색깔은 육안으로 판정할 때 비슷한 황갈색을 띄었다.

이들 d-CLA 시료와 r-CLA 시료의 색깔을 정확히 판정하기 위해서 이들의 $\mathrm{L}, \mathrm{a}, \mathrm{b}$ 값을 색도계를 이용하여 측정하여 비교 하였다(Table 1). c-CLA 시료의 L, a, b 는 각각 $88.80,19.88$,

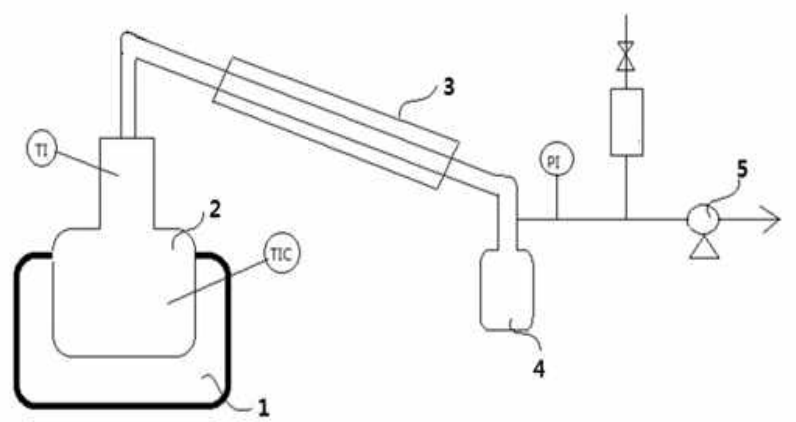

Fig. 1. A diagram for distillation apparatus set. Parts identification: 1 , heating mental; 2 , three-neck flask; 3 , cooling condenser; 4 , distilled CLA receiver; 5 , vacuum pump; TI, thermal indicator; TIC, thermal immersed controller; and PI, pressure indicator.

Table 1. Effect of distillation conditions on the color description parameters of d- and r-CLA samples

\begin{tabular}{|c|c|c|c|c|}
\hline & \multirow{2}{*}{ Samples ${ }^{1)}$} & \multicolumn{3}{|c|}{ Parameter of color description } \\
\hline & & Brightness (L) & Red/green (a) & Yellow/blue (b) \\
\hline c-CLA & & $88.80^{2)}$ & 19.88 & 58.22 \\
\hline \multirow{4}{*}{ d-CLA } & $10 \mathrm{mmHg} 220^{\circ} \mathrm{C}$ & 102.48 & -0.32 & 1.67 \\
\hline & $10 \mathrm{mmHg} 235^{\circ} \mathrm{C}$ & 99.73 & -2.99 & 10.39 \\
\hline & $10 \mathrm{mmHg} 240^{\circ} \mathrm{C}$ & 98.78 & -2.06 & 11.79 \\
\hline & $20 \mathrm{mmHg} 260^{\circ} \mathrm{C}$ & 98.79 & -2.32 & 12.54 \\
\hline \multirow{4}{*}{ r-CLA } & $10 \mathrm{mmHg} 220^{\circ} \mathrm{C}$ & 69.67 & 19.49 & 94.63 \\
\hline & $10 \mathrm{mmHg} 235^{\circ} \mathrm{C}$ & 68.12 & 21.66 & 95.54 \\
\hline & $10 \mathrm{mmHg} 240^{\circ} \mathrm{C}$ & 70.40 & 19.43 & 94.76 \\
\hline & $20 \mathrm{mmHg} 260^{\circ} \mathrm{C}$ & 62.27 & 28.06 & 98.16 \\
\hline
\end{tabular}

${ }^{1}$ Sample descriptions: d-CLA and r-CLA samples were obtained by distillation of c-CLA sample for 30 min at a given distillation condition.

${ }^{2)}$ Standard deviation is less than $10 \%$ of mean value.

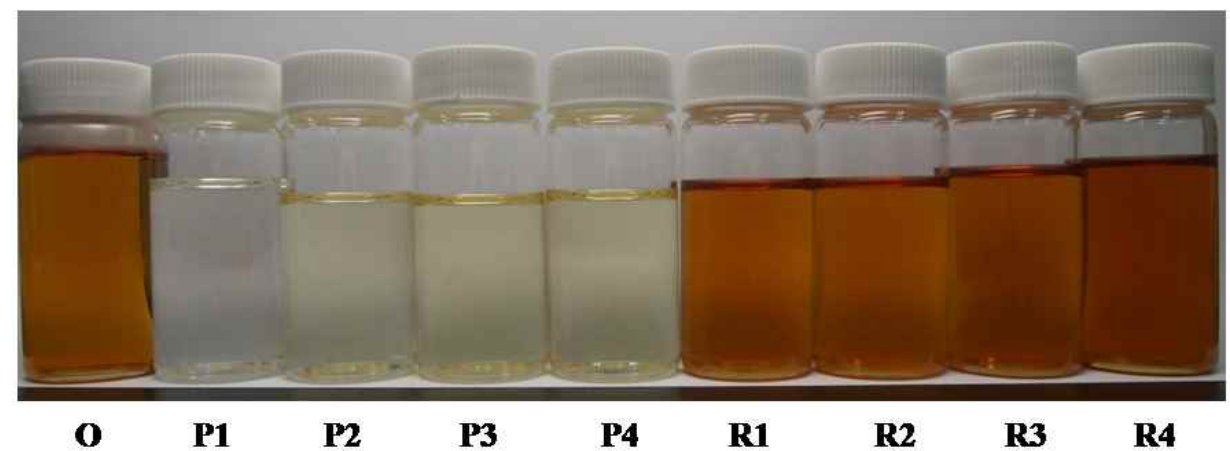

Fig. 2. The d- and r-CLA samples obtained by distillation for $30 \mathrm{~min}$ using the distillation apparatus shown in Fig. 1. Identification of CLA samples: c-CLA sample (O); d-CLA samples $\left(\mathrm{P} 1,10 \mathrm{mmHg}-220^{\circ} \mathrm{C}\right.$; $\mathrm{P} 2,10 \mathrm{mmHg}-235^{\circ} \mathrm{C}$; $\mathrm{P} 3,10 \mathrm{mmHg}-240{ }^{\circ} \mathrm{C}$; and $\mathrm{P} 4,20 \mathrm{mmHg}-260^{\circ} \mathrm{C}$ ); and r-CLA samples (R1, $10 \mathrm{mmHg}-220^{\circ} \mathrm{C}$; R2, $10 \mathrm{mmHg}-235^{\circ} \mathrm{C}$; R3, $10 \mathrm{mmHg}-240^{\circ} \mathrm{C}$; and $\mathrm{R} 4,20$ $\left.\mathrm{mmHg}-260^{\circ} \mathrm{C}\right)$. 
58.22 로서 이들 값이 상대적으로 높았지만, $10 \mathrm{mmHg}-220^{\circ} \mathrm{C}$ 에 서 얻은 무색 d-CLA 시료의 L은 102.48 로 c-CLA의 L 치보다 높아졌고 $\mathrm{a}$ 와 $\mathrm{b}$ 치는 각각 -0.32 와 1.67 로 급격히 감소하였다. 이와 같은 결과는 c-CLA의 황갈색이 없어 졌음을 의미한다. 다른 증류조건에서 얻은 d-CLA 시료의 L 값은 c-CLA의 L 값보다 10 정도 높아졌고, a 값은 -2.06 2.99로 많이 낮아졌고, $\mathrm{b}$ 값 또한 10.39 12.54로 크게 낮아졌으나 이들의 수치는 10 $\mathrm{mmHg}-220^{\circ} \mathrm{C}$ 조건에서 얻은 $\mathrm{d}-\mathrm{CLA}$ 시료의 $\mathrm{L}, \mathrm{a}, \mathrm{b}$ 값의 변화 보다는 크지 않았다. 이러한 결과는 $10 \mathrm{mmHg}-220^{\circ} \mathrm{C}$ 에서 얻 은 d-CLA 시료가 다른 증류조건에서 얻은 d-CLA 시료보다 무색에 가깝다는 것을 의미 한다. 여러 증류조건에서 얻은 $\mathrm{r}$-CLA 시료의 경우 $\mathrm{L}, \mathrm{a}, \mathrm{b}$ 값은 서로 유사하였지만, 20 $\mathrm{mmHg}-260^{\circ} \mathrm{C}$ 에서 얻은 r-CLA 시료가 다른 r-CLA 시료보다 $\mathrm{L}$ 값은 낮고, $\mathrm{b}$ 값이 높아 다소 어두운 색깔을 나타내고 있음을 알 수 있었다. 이와 같은 결과는 Fig. 2에서의 육안으로 구별한 결과와 동일하다.

유지에 함유된 색소는 규조토로 여과하거나 활성탄 등과 같은 흡착제에 색소를 흡착시켜 제거하거나 감압으로 색소 를 제거할 수 있다[13,19]. Safflower oil과 같은 식물성유를 사용하여 합성한 CLA 시료에 함유된 색소도 실험실에서나 산업적으로 규조토 여과로 제거하지만, 완전히 제거되지 않 기 때문에 감압증류의 방법이 사용되고 있다. 본 연구에서 도 감압증류로 CLA 시료에 함유된 색소를 효율적으로 제거 할 수 있었다.

CLA 이성체 중 cis 이성체는 산이나 열에 대한 안정성이 약하여 산 처리나 열처리에 의해 trans 이성체로 쉽게 전환 된다[13,22]. 따라서 고온 증류과정에서 CLA 이성체의 변화
정도를 조사하기 위하여 c-CLA 시료의 CLA 이성체 조성과 다양한 증류조건에서 얻은 d-CLA 시료와 r-CLA 시료의 CLA 이성체 조성을 비교하였다. 먼저 Fig. 3에서는 대표적으로 $\mathrm{c}$-CLA 시료와 $10 \mathrm{mmHg}-220^{\circ} \mathrm{C}$ 증류조건에서 얻은 d-CLA 시 료의 GC chromatogram을 나타내었고, 이들 GC chromatogram을 근거로 하여 계산한 CLA 이성체 조성을 Table 2에 나타내었다. c-CLA 시료의 c9,t11-CLA, t10,c12-CLA 및 $\mathrm{t}, \mathrm{t}-\mathrm{CLA}$ 의 조성은 각각 $34.6 \%, 35.8 \%$ 및 $2.2 \%$ 였다. 여러 조건 에서 증류한 d-CLA 시료의 이들 이성체 조성 중 c9,t11-CLA와 $\mathrm{t} 10, \mathrm{c12}-\mathrm{CLA}$ 의 조성에는 큰 변화가 없었고 t,t-CLA의 함량도 큰 차이가 없어, 한국식품안전청(KFDA)의 기준치인 $3.0 \%$ 이 하였다. 그러나 r-CLA 시료의 경우도 c9,t11-CLA와 $\mathrm{t} 10, \mathrm{c} 12-\mathrm{CLA}$ 의 조성에는 큰 변화가 없었지만, $\mathrm{t}, \mathrm{t}-\mathrm{CLA}$ 시료의 조성은 $2.0 \% \sim 3.5 \%$ 로 약간 증가하였다. 특히 $10 \mathrm{mmHg}-220^{\circ} \mathrm{C}$ 에서 얻은 r-CLA 시료의 $\mathrm{t}, \mathrm{t}-\mathrm{CLA}$ 조성은 $2.0 \%$ 로 다른 r-CLA 시료의 $\mathrm{t}, \mathrm{t}-\mathrm{CLA}$ 조성보다 낮았다. CLA의 이성체 중 c9,t11-CLA나 t10,c12-CLA 등의 cis-형 CLA는 가열이나 산 처 리에 의해 쉽게 trans-형 CLA로 안정화되어 이들은 각각 t9,t11-CLA와 t10,t12-CLA로 전환된다. 따라서 산의 양과 온도 등은 이들 CLA의 이성체를 정량하는데 중요한 인자로 작용하 고 있다[22]. 그러나 본 연구에서 감압증류 한 조건에 의해서는 감압상태이어서 cis 형이 trans 형으로의 전환은 크지 않았다.

본 연구에서 c-CLA 시료를 증류하여 무색의 d-CLA 시료는 얻었지만, 순도가 높은 색소는 얻지를 못하였고, 황갈색이 있 는 r-CLA 시료를 얻었다. c-CLA를 $10 \mathrm{mmHg}-220^{\circ} \mathrm{C}$ 에서 증류 하여 얻은 d-CLA 시료 및 r-CLA 시료의 이성체 조성이 크게 다르지 않고, 다만 색깔에 차이가 있어 이 r-CLA 시료와 d-
(A)

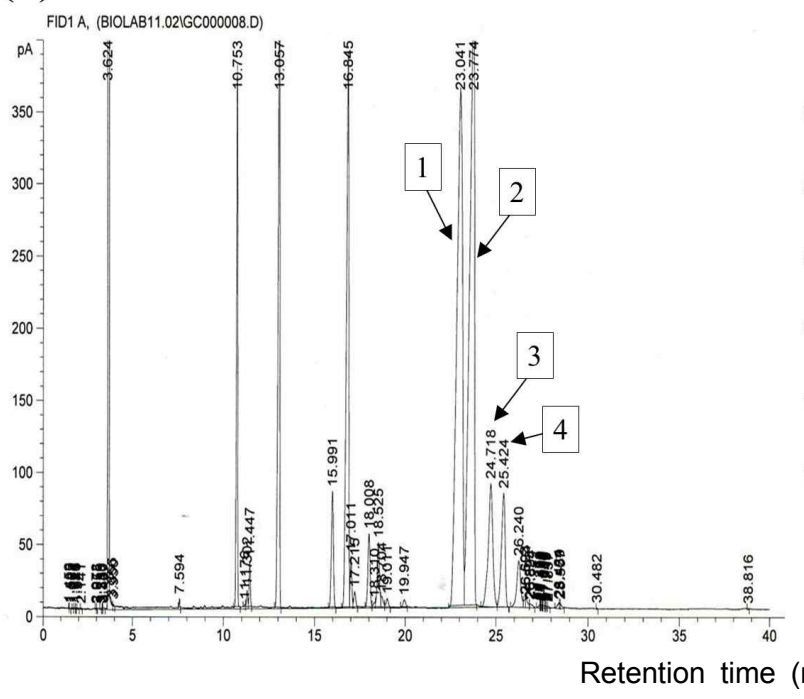

(B)

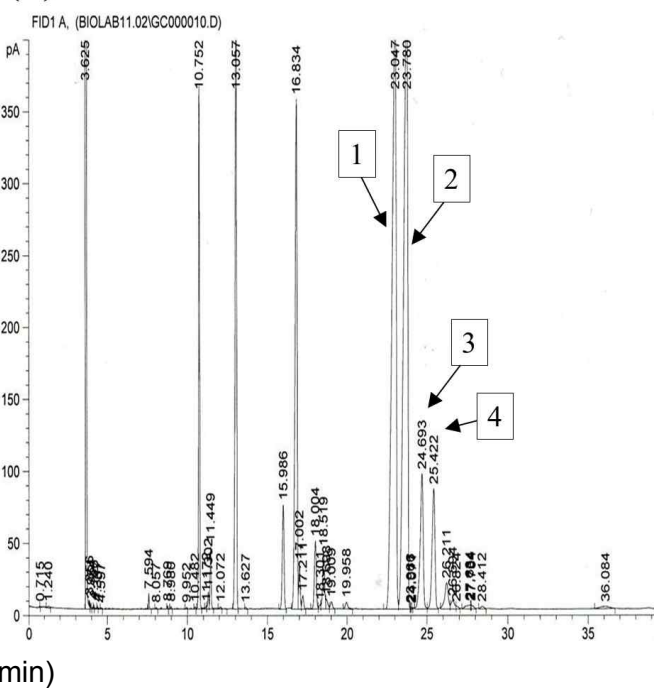

Fig. 3. Typical GC chromatograms of c-CLA (A) and d-CLA samples (B). Identification of CLA isomers: 1, c9,t11-CLA; 2, t10,c12-CLA; 3, c,c-CLA; and 4, t,t-CLA. 
CLA시료를 아래 세포독성 연구를 위한 시료로 사용하였다.

\section{$\mathrm{r}-\mathrm{CLA}$ 시료의 세포독성}

c-CLA 시료에 함유된 색소의 세포독성을 조사하기 위하여 색소가 함유되어 있는 r-CLA 시료의 인체암세포인 MCF-7, PC-3, A-549, HT-29와 인체 정상세포 인SK-N-SH 세포에 대해 독성을 조사하였다. 증류조건 $10 \mathrm{mmHg}-220^{\circ} \mathrm{C}$ 에서 얻은 $\mathrm{r}$-CLA 시료의 세포독성을 동일한 증류조건에서 얻은 d-CLA 시료와 c-CLA 시료의 세포독성을 비교하여 c-CLA 색깔의 독 성을 추정하였다.

Fig. 4A에서는 CLA의 항암성이 가장 많이 연구된 MCF-7 세포에 대한 독성을 나타내고 있다. r-CLA 시료의 MCF-7세포 에 대한 세포독성은 농도에 따라 증가하였지만 전 처리 농도
에서 c-CLA 시료나 d-CLA 시료보다 낮았다. 특히 $40 \mu \mathrm{M}$ 시료 농도에서 r-CLA 시료는 $17 \%$ 세포독성을 나타내어 c-CLA 시 료 33\%, d-CLA 시료 25\% 보다 낮았다. A-549 세포에 대한 $\mathrm{r}$-CLA 시료의 세포독성도 농도에 따라 증가하여 $40 \mu \mathrm{M}$ 농도 에서 $22 \%$ 였다. 그러나 c-CLA 시료와 d-CLA 시료의 세포독성 과 차이가 없었다(Fig. $4 \mathrm{~B}$ ).

PC-3 세포에 대한 r-CLA 시료의 세포독성은 농도에 따라 증가하였지만, d-CLA 시료와 c-CLA 시료와 유사하였다(Fig. 5A). $40 \mu \mathrm{M}$ 시료 농도에서 r-CLA 시료는 $25 \%$, d-CLA 시료는 $32 \%, \mathrm{c}-\mathrm{CLA}$ 시료는 $22 \%$ 를 나타내었지만, 시료에 따른 유의성 은 없었다. 또한 r-CLA 시료의 HT-29 세포에 대한 세포독성은 $10 \mu \mathrm{M}$ 처리농도에서 c-CLA 시료와 d-CLA 시료 보다 유의성 있게 낮았으나, $40 \mu \mathrm{M}$ 처리농도에서는 차이가 없었다

Table 2. Effect of distillation conditions on the composition of CLA isomers in d-and r-CLA samples

\begin{tabular}{ccccc}
\hline & \multirow{2}{*}{ Samples $^{1)}$} & \multicolumn{3}{c}{ Composition of CLA isomer (\%) } \\
\cline { 3 - 5 } & & c9t11-CLA & t10c12-CLA & t,t-CLA \\
\hline \multirow{2}{*}{ c-CLA } & $10 \mathrm{mmHg}-220^{\circ} \mathrm{C}$ & $34.6^{2)}$ & 35.8 & 2.2 \\
\hline \multirow{2}{*}{$\mathrm{d}-\mathrm{CLA}$} & $10 \mathrm{mmHg}-235^{\circ} \mathrm{C}$ & 34.8 & 36.7 & 1.6 \\
& $10 \mathrm{mmHg}-240^{\circ} \mathrm{C}$ & 34.5 & 35.9 & 2.2 \\
& $20 \mathrm{mmHg}-260^{\circ} \mathrm{C}$ & 34.7 & 36.8 & 2.1 \\
\hline \multirow{3}{*}{ r-CLA } & $10 \mathrm{mmHg}-220^{\circ} \mathrm{C}$ & 34.2 & 36.8 & 2.1 \\
& $10 \mathrm{mmHg}-235^{\circ} \mathrm{C}$ & 33.6 & 36.9 & 3.0 \\
& $10 \mathrm{mmHg}-240^{\circ} \mathrm{C}$ & 34.3 & 35.9 & 3.5 \\
& $20 \mathrm{mmHg}-260^{\circ} \mathrm{C}$ & 34.5 & 35.0 & 3.0 \\
\hline
\end{tabular}

${ }^{1)}$ Sample descriptions: d-CLA and r-CLA samples were obtained by distillation of c-CLA sample for 30 min at a given distillation condition.

${ }^{2)}$ Standard deviation is less than $10 \%$ of mean value.

(A)

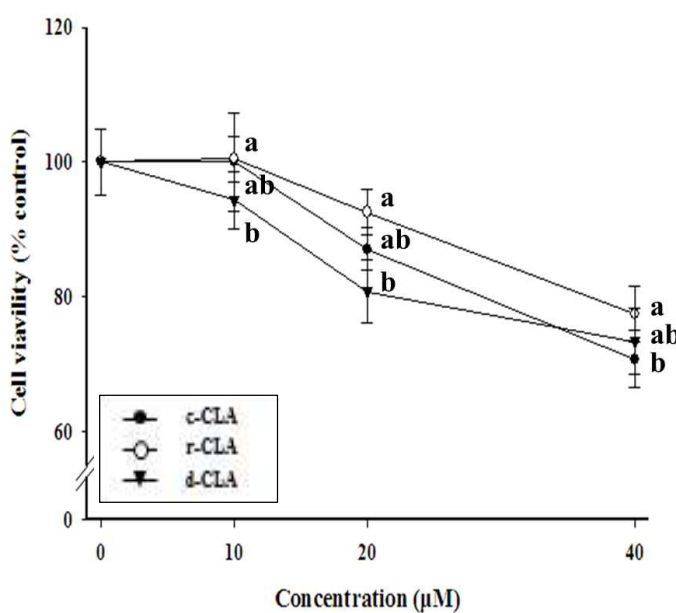

(B)

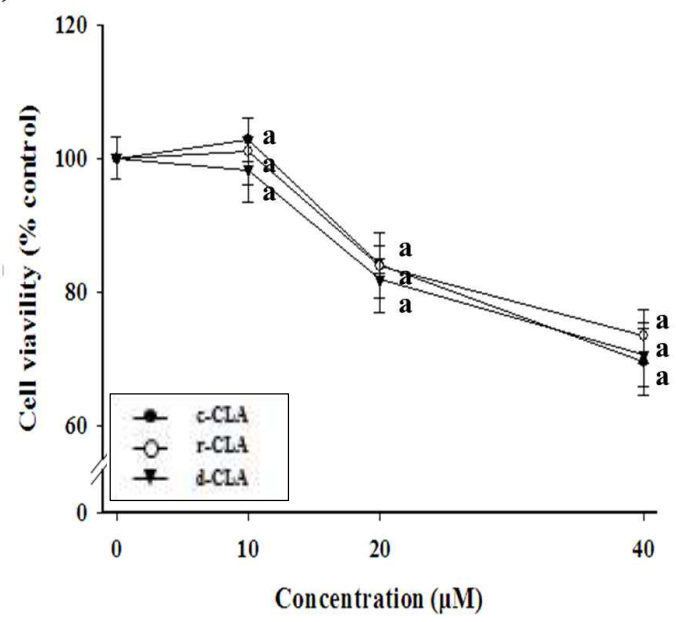

Fig. 4. Effect of r-CLA sample on the proliferation of human breast cancer MCF-7 cells (A) and human lung cancer A-549 cells (B) grown for 2 days. $\mathrm{d}$ - and r-CLA samples were obtained by distillation of c-CLA sample for $30 \mathrm{~min}$ at a $10 \mathrm{mmHg}-220^{\circ} \mathrm{C}$. Values represent mean $\pm S D(n=3)$. Means with same lowercase letters at same concentrations are not significantly different at $p<0.05$ by Duncan's multiple range test. 
(A)

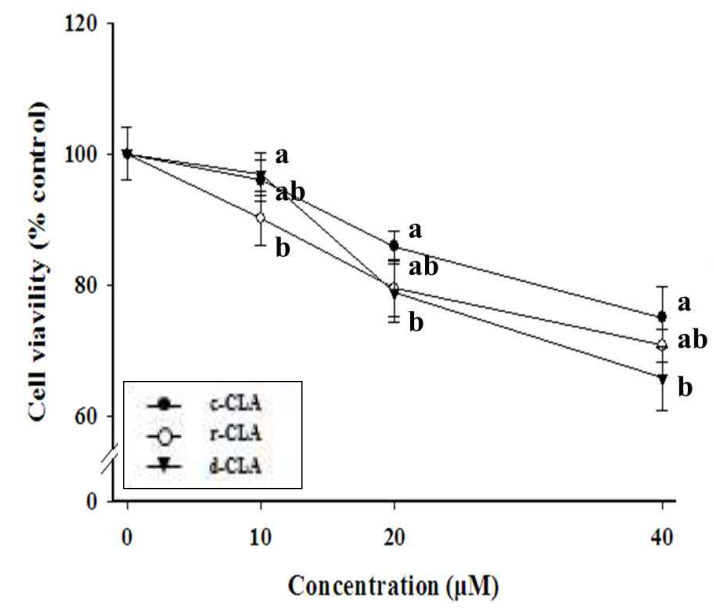

(B)

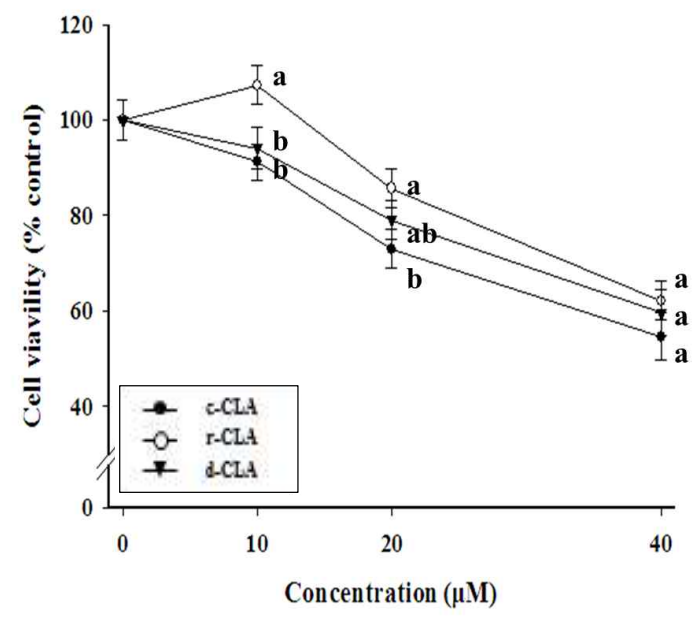

Fig. 5. Effect of r-CLA sample on the proliferation of human prostate cancer PC-3 cells (A) and human colon cancer HT-29 cells (B) grown for 2 days. $\mathrm{d}$ - and r-CLA samples were obtained by distillation of c-CLA sample for $30 \mathrm{~min}$ at a $10 \mathrm{mmHg}-220^{\circ} \mathrm{C}$. Values represent mean $\pm S D(n=3)$. Means with same lowercase letters at same concentrations are not significantly different at $p<0.05$ by Duncan's multiple range test.

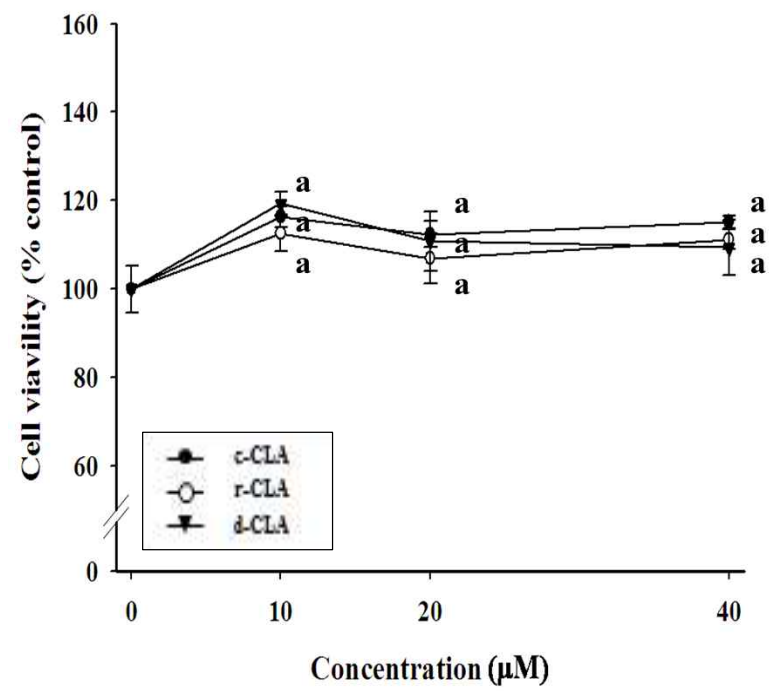

Fig. 6. Effect of r-CLA sample on the proliferation of human neuroblastoma SK-N-SH cells grown for 2 days. d- and $r$-CLA samples were obtained by distillation of c-CLA sample for $30 \mathrm{~min}$ at a $10 \mathrm{mmHg}-220^{\circ} \mathrm{C}$. Values represent mean \pm SD $(n=3)$. Means with same lowercase letters at same concentrations are not significantly different at $p<0.05$ by Duncan's multiple range test.

(Fig. 5B). $40 \mu \mathrm{M}$ 처리농도에서 r-CLA 시료는 34\%, d-CLA 시료는 $40 \%, \mathrm{c}-\mathrm{CLA}$ 시료는 $42 \%$ 독성을 나타내어 다른 암세포 에 대한 독성보다 다소 높은 독성을 나타내었다.

$\mathrm{r}-\mathrm{CLA}$ 시료의 정상세포인 SK-N-SH에 대한 세포독성을 조 사하였다(Fig. 6). 암세포와는 달리 r-CLA 시료의 SK-N-SH 세 포에 대한 독성은 없었다. 오히려 $10 \mu \mathrm{M}$ 농도에서는 SK-N-SH 세포 생육을 대조구(control: $0 \mu \mathrm{M}$ )에 비해 유의성 있게 $10 \%$
증가 시켰고, $40 \mu \mathrm{M}$ 농도에서도 $8 \%$ 증가시켰다. 이와 같은 효과는 c-CLA 시료와 d-CLA 시료에서도 나타났는데 이들 CLA 시료 사이에서의 유의성은 없었다.

많은 연구에서 linoleic acid 또는 linoleic acid를 함유한 유 지로부터 합성된 CLA (여러 이성체의 혼합물)나 CLA의 이성 체인 c9,t11-CLA가 MCF-7 세포와 같은 다양한 인체 암세포에 대해 세포독성을 나타내고 있음이 밝혀졌다. 본 연구에서 무 색의 d-CLA 시료(여러 이성체의 혼합물)가 MCF-7, A-549, HT-29 및 PC-3 암세포에 대해 강한 세포독성을 나타내었고, 이 d-CLA 시료의 세포독성효과는 색소가 함유 된 r-CLA 시료 나 c-CLA 시료와 유사하여 유의성이 있는 차이는 없었다. 그 러나 이들은 정상세포의 생육에는 오히려 낮은 처리 농도에서 는 생육을 증가시키는 효과가 있었다. CLA의 정상세포에 대 한 세포독성에 관한 연구는 많지 않지만, CLA가 MCF-10A세 포의 생육을 촉진하는 보고와 일치하였다[23]. 따라서 CLA 시료에 함유되어 있는 황갈색의 색깔은 암세포나 정상세포의 생육에 아무런 영향을 미치지 않음을 알 수 있었다.

결론적으로, c-CLA 시료를 $10 \mathrm{mmHg}-220^{\circ} \mathrm{C}$ 에서 증류하여 무색의 d-CLA 시료를 얻을 수 있었고, 이때 얻은 r-CLA 시료 (황갈색을 함유한 시료)는 인체암세포 (MCF-7. A-549, HT-29, PC-3)와 신경모세포 (SK-N-SH)에 대한 세포독성은 d-CLA와 비교하여 차이가 없어 c-CLA에 함유된 색소는 세포의 생육에 아무런 영향을 미치지 않았다.

\section{감사의 글}

이 연구는 경상대학교 BK21 program 지원사업과 중소기업 청 산학연공동기술개발 사업(No. 00043757, 2010년)에 의해 
수행되었습니다.

\section{References}

1. Albers, R., Van der Wielen, R. P. J., Brink, E. J., Hendriks, H. F. J., Doro- vska-Taran, V. N. and Mohede, I. C. M. 2003. Effects of cis- 9 , trans- 11 and trans-10, cis-12 conjugated linoleic acid (CLA) isomers on immune function in healthy men. Eur. J. Clin. Nutr. 57, 595-603.

2. Beppu, F., Hosokawa, M., Tanaka, L., Kohno, H., Tanaka, T. and Miyashita, K. 2006. Potent inhibitory effect of trans9, trans11 isomer of conjugated linoleic acid on the growth of human colon cancer cells. J. Nutr. Biochem 17, 830-836.

3. Biaek, A., Tokarz, A., Dudek, A., Kazimierska, W. and Bielecki, W. 2010. Influence of diet enriched with conjugated linoleic acids on their distribution in tissues of rats with DMBA induced tumors. Lipids Health Dis. 9, 1-9.

4. Chen, S., Lin, Y., Huang, H., Hsu, W., Houng, J. and Huang, C. 2012. Effect of conjugated linoleic acid supplementation on weight loss and body fat composition in a Chinese population. Nutrition 28, 559-565.

5. Coakley, M., Ross, R. P., Nordgren, M., Fitzgerald, G., Devery, R. and Stanton, C. 2003. Conjugated linoleic acid biosynthesis by human-derived Bifidobacterium species. J. Appl. Microbiol. 94, 138-145.

6. Ha, Y. L., Grimm, N. K. and Pariza, M. W. 1987. Anticarcinogens from fried ground beef: heat-altered derivatives of linoleic acid. Carcinogenesis 8, 1881-1887.

7. Ha, Y. L. and Jeong, S. B. 2010. Effects of conjugated linoleic acid on body fat reduction and physical exercise enhancement of obese male middle school students. J. Life Sci. 20, 1844-1850.

8. Ha, Y. L., Storkson, J. and Pariza, M. W. 1990. Inhibition of benzo(a)pyrene-induced mouse forestomach neoplasia by conjugated dienoic derivatives of linoleic acid. Cancer Res. 50, 1097-1101.

9. Halade, G. V., Rahman, M. M. and Fernandes, G. 2009. Effect of CLA isomers and their mixture on aging C57Bl/6J mice. Eur. J. Nutr. 48, 409-418.

10. Hernandez-Mendoza, A., Lopez-Hernandez, A., Hill Jr, C. G. and Garcia, H. S. 2009. Bioconversion of linoleic acid to conjugated linoleic acid by Lactobacillus reuteri under different growth conditions. J. Chemical Technol. Biotechnol. 84, 180-185.

11. Islam, M. A., Kim, Y. S., Jang, W. J., Lee, S. M., Kim, H. G., Kim, S. Y., Kim, J. O. and Ha, Y. L. 2008. A mixture of trans, trans conjugated linoleic acid induces apoptosis in MCF-7 human breast cancer cells with reciprocal expression of Bax and Bcl-2. J. Agric. Food Chem 56, 5970-5976.

12. Jang, W. J. 2006. Production of natural CLA by submerged liquid culture of mushrooms. Master thesis, Gyeongsang
National University, Jinju, Korea.

13. Juanéda, P., De la Pérrière, S., Sébédio, J. and Grégoire, S. 2003. Influence of heat and refining on formation of CLA isomers in sunflower oil. J. Am Oil Chem Soc. 80, 937-940.

14. Kelley, N. S., Hubbard, N. E. and Erickson, K. L. 2007. Conjugated linoleic acid isomers and cancer. J. Nutr. 137, 2599-2607.

15. Kim, Y. J. 2003. Partial inhibition of biohydrogenation of linoleic acid can increase the conjugated linoleic acid production of Butyrivibrio fibrisolvens A38. J. Agric. Food Chem 51, 4258-4262.

16. Kim, S. J., Park, K. A., Jung, H. Y., Kim, J. O. and Ha, Y. L. 2000. Preparation of a large quantity of cis 9 , trans -11 and trans 10, cis-12 conjugated linoleic acid (CLA) isomers from synthetic CLA. J. Food Sci. Nutr. 5, 86-92.

17. Kwon, J. M., Moon, Y. G., Kim, Y. S., Jung, J. Y., Ha. Y. L. and Yang, J. K. 2011. Effects of extraction methods of medicinal plants on the growth human of neuroblastoma SK-N-SH Cells. J. Life Sci. 21, 1190-1198.

18. Liavonchanka, A. and Feussner, I. 2008. Biochemistry of PUFA double bond isomerases producing conjugated linoleic acid. ChemBioChem 9, 1867-1872.

19. Liu, G. and Chen. G. 2012. Study on the decolorization of biodiesel from waste cooking oil. Adv. Mater. Res. 347, 3781-3787.

20. Mitchell, P. L., Langille, M. A., Currie, D. L. and McLeod, R. S. 2005. Effect of conjugated linoleic acid isomers on lipoproteins and atherosclerosis in the Syrian golden hamster. Biochim Biophys. Acta. 1734, 269-276.

21. Ochoa, J. J., Farquharson, A. J., Grant, I., Moffat, L. E., Heys, S. D. and Wahle, K. W. J. 2004. Conjugated linoleic acids (CLAs) decrease prostate cancer cell proliferation: Different molecular mechanisms for cis- 9 , trans- 11 , and trans-10 cis- 12 isomers. Carcinogenesis 25, 1185-1191.

22. Park, S. J., Park, C. W., Kim, S. J., Kim, J. K., Kim, Y. R., Park, K. A., Kim, J. O. and Ha, Y. L. 2002. Methylation methods for the quantitative analysis of conjugated linoleic acid (CLA) isomers in various lipid samples. J. Agric. Food Chem 50, 989-996.

23. Rakib, M. A., Kim, Y. S., Jang, W. J., Choi, B. D., Kim, J. O., Kong, I. K. and Ha, Y. L. 2010. Attenuation of 12-O-tetradecanoylphorbol-13-acetate (TPA)-induced gap junctional intercellular communication (GJIC) inhibition in MCF-10A cells by c9,t11-conjugated linoleic acid. J. Agric. Food Chem 58, 12022-12030.

24. Rakib, M. A., Kim, Y. S., Jang, W. J., Jang, J. S., Kang, S. J. and Ha, Y. L. 2011. Preventive effect of $t, t$-conjugated linoleic acid on 12-O-tetradecanoyl-phorbol-13-acetate-induced inhibition of gap junctional intercellular communication in human mammary epithelial MCF-10A Cells. J. Agric. Food Chem 59, 4164-4170. 
초록 : Conjugated linoleic acid 황갈색의 인체암세포와 인체정상세포에 대한 세포독성

지유철 ${ }^{1}$ 안채린 ${ }^{1} \cdot$ 서양곤 $^{2} \cdot$ 서정세 ${ }^{3} \cdot$ 김정옥 ${ }^{4} \cdot$ 하영래 $^{1} \star$

$\left({ }^{1}\right.$ 경상대학교 대학원 응용생명과학부, ${ }^{2}$ 경상대학교 화학생명공학과, ${ }^{3}$ 경상대학교 기계공학과, ${ }^{4}($ 주 $) \mathrm{HK}$ 바이 오텍)

체지방감소 효과가 있는 시판 conjugated linoleic acid (CLA)의 색깔을 제거하고 이 색깔의 세포독성에 관한 연구를 하였다. 황갈색의 시판 CLA 제품을 구입하여 crude CLA (c-CLA) 시료로 하였다. c-CLA 시료를 감압증 류 $\left(10 \mathrm{mmHg}-220^{\circ} \mathrm{C}, 10 \mathrm{mmHg}-235^{\circ} \mathrm{C}, 10 \mathrm{mmHg}-240^{\circ} \mathrm{C}, 20 \mathrm{mmHg}-260^{\circ} \mathrm{C}\right.$; 30분)하여 증류된 CLA (distilled CLA; $\mathrm{d}-\mathrm{CLA}$ ) 시료와 증류되지 않고 남아있는 황갈색 CLA (residual CLA; r-CLA) 시료로 분리하였다. $10 \mathrm{mmHg}-220^{\circ} \mathrm{C}$ 에서 증류하여 얻은 d-CLA 시료의 색깔은 L (brightness), a (red/blue), b (yellow/green)로 분석한 결과 무색에 가까웠고 r-CLA 시료는 황갈색이었고, 이들 두 CLA 시료의 CLA 이성체 조성은 변하지 않았다. 따라서 10 $\mathrm{mmHg}-220^{\circ} \mathrm{C}$ 에서 얻은 r-CLA 시료의 인체암세포(유방암 MCF-7. 폐암 A-549, 직장암 HT-29, 전립선암 PC-3)와 인체 정상세포(신경모세포 SK-N-SH)에 대한 세포독성을 d-CLA 시료와 비교하였다. 이들 암세포와 정상세포에 $\mathrm{r}$-CLA 시료와 d-CLA 시료 처리 2일 후의 세포독성에는 차이가 없었다. 따라서 본 연구에서 c-CLA 시료에 함유 된 색소는 $10 \mathrm{mmHg}-220^{\circ} \mathrm{C}$ 로 감압증류 하여 제거할 수 있었고, r-CLA 시료의 세포독성은 d-CLA 시료의 세포독 성과 차이가 없었다. 이와 같은 결과는 c-CLA 시료에 함유된 색소는 세포생육에 아무런 영향을 미치지 않고 인체 에 아무런 영향을 미치지 않음을 의미한다. 